\title{
Modification of power transmission system of pigeonpea stem cutter
}

\section{A.M. GORE AND S.K. THAKARE}

Received : 17.10.2013; Revised : 07.03.2015; Accepted : 18.03.2015

See end of the Paper for authors' affiliation

Correspondence to :

\section{A.M. GORE}

Department of Farm Power And Machinery, College of Agricultural Engineering and Technology, Dr. Panjabrao Deshmukh Krishi Vidyapeeth, AKOLA (M.S.) INDIA
-ABSTRACT : A pigeonpea (Cajanus cajan L. Mills) stem cutter was developed in the department and its performance was evaluated in the field. During testing of equipment the problem were observed in the transmission of power from PTO to cutter unit and conveying of cut plant. Thus, modification of power transmission system of the equipment was carried out in the department of Farm Power and Machinery, Dr. Panjabrao Deshmukh Krishi Vidyapeeth, Akola. Among with the modification in power transmission system, the conveying system was also modified. The cut plant were bending in opposite direction of travel during the conveying and getting chocked between the conveying tray and cutting unit. In view to avoid this a plant guiding arrangement was introduced on the equipment. The modified pigeonpea stem cutter was tested in the field at the operating speed of 3 and $3.5 \mathrm{~km} / \mathrm{h}$. and was found working satisfactory. The cutting efficiency of the modified implement was increased due to the change in position of cutter bar and efficiency of conveying was improved tremendously with the modification of conveying tray and introduction of plant guiding arrangement. The maximum cutting efficiency was found 81.25 per cent and 80.00 per cent at $3 \mathrm{~km} / \mathrm{h}$ and $3.5 \mathrm{~km} / \mathrm{h}$ speeds, respectively. Whereas the field efficiency was observed as 72.59 per cent and 74.28 per cent at the above mentioned speeds, respectively. The plant damage was found 10.29 per cent and 10.93 per cent at $3 \mathrm{~km} / \mathrm{h}$ and $3.5 \mathrm{~km} / \mathrm{h}$ speed of operation, respectively. The cost of operation was observed 42.07 per cent less as compared to the manual harvesting of the pigeonpea crop.

GEY WORDS : Power transmission system, Stem cutter, Plant guiding arrangement, Cutting efficiency, Field efficiency

- HOW TO CITE THIS PAPER : Gore, A.M. and Thakare, S.K. (2015). Modification of power transmission system of pigeonpea stem cutter. Internat. J. Agric. Engg., 8(1) : 103-108. 